\title{
Travesty: The Expression of the Agrarian Society as Cultural Negotiation at the Amal Play at Pulau Belimbing II Sub-Village, Kuok Village, Kuok District, Kampar Regency, Riau Province
}

\author{
Saaduddin ${ }^{1,}$ :Sherli Novalinda ${ }^{2,}$ Tika Alfareta ${ }^{3}$ \\ 1,2,3, Faculty of Performance Arts, Indonesian Institute of Arts Padangpanjang, West Sumatera \\ "Corresponding author: hanyadidin@gmail.com, saaduddin@isi-padangpanjang.ac.id, sherlinovalinda@gmail.com, \\ tikaelfaretta96@gmail.com
}

\begin{abstract}
The Amal play is a form of folk theatre in Sandiwara Amal in Pulau Belimbing II Sub-Village, Kuok Village, Kuok District, Kampar Regency, Riau Province since the 1950's. Until today, the Amal play is always performed every year on the first week of the Idul Fitri celebration. There is no concept of a fixed script in the Amal play, as it is driven by the improvisation motives of the scriptwriter. In addition, the female characters are played by male actors, a cultural negotiation in the order of society to celebrate Idul Fitri. On one hand, it does not take into account the Islamic laws by recognizing the travesty motive in the cultural play. This paper assumes that the travesty pattern is deliberately carried out as an effort of community protection toward a cultural awareness that is full of meaning as a negotiation effort. This is what must be examined and investigated as an intriguing topic in the form of research.
\end{abstract}

Keywords: Amal play, travesty negotiation

\section{INTRODUCTION}

Since the 1950's, Pulau Belimbing II Sub-Village, Kuok Village, Kuok District, Kampar Regency, Riau Province[1] has been familiar with a form of folk theatre which is called the Amal play by the local community. The revenue of ticket sales is managed for infrastructures and social activities at Pulau Belimbing II Sub-Village [2]. The Amal play is held by the people of Pulau Belimbing II Sub-Village every year on 1 Syawal in the Islamic month of Hijriyah until the first week of the month of Syawal.

As a form of folk theatre, the Amal play does not recognize the formal script of a play as typically used in the realist theatres; instead, it uses instructions or improvisations for the actors, in addition to a premise or pattern to give a dramatic structure. The show format presented in the Amal play, based on Jakob Soemardjo's ideas, can be categorized as folk theatre [3].

In the Amal play, the female characters are played by male actors. The travesty refers to a pronoun for a male who plays a female role in a play [4] used in the presentation of Amal play. In Amal play, travesty has a different meaning from the notion of Sutarto [5] who argue that the expression refers to a secular form of art which gives recognition to transgender people.

The Amal play is interesting to study mainly because, as a form of folk theatre, the Amal play is unique in its presentation form as it still uses the travesty approach in the presentation for the public. This paper assumes that the travesty pattern is deliberately carried out as an effort of community protection toward a cultural awareness that is full of meaning as a negotiation effort.

\section{RESEARCH METHODOLOGY}

Research was carried out using the field study principles which required a direct visit to the research location at Pulau Belimbing II Sub-Village. The visit was set to the site where the Amal play took place in order to see the live performance of Amal play on the Idul Fitri holiday at 1 Syawal, as well as to interview the actors who had played the roles since the 1950's. Moreover, a literature study was also conducted to find 
a previous study on the Amal play between 2015-2020. Data were obtained from informants during the interview sessions, and verification on the data of the previous study was done, as well. The obtained data were transcribed and translated into Indonesian.

\section{RESULTS AND DISCUSSION}

\subsection{The Agrarian Condition and Ecological Components of Amal Play}

The Pulau Belimbing II Sub-Village is located by the Kampar river. The Pulau Belimbing II Sub-Village has a lush and fertile which gives birth to the agrarian community. The Pulau Belimbing II Sub-Village is located in the remote area of the Kuok village, in the highway of Riau-West Sumatra [6].

The origin of the name Pulau Belimbing or the Starfruit Island in the context of the village history has never been studied. There was only one study who referenced the village as research data [2]. Information is passed between generations orally and becomes a formal icon. From the cultural point of view, the name Belimbing (starfruit) can be associated with the starfruit trees in the village. The use of the fruit in various dishes eventually makes the name stuck among the community and used as the village name.

\subsection{Amal Play: The Expressions of Agrarian Community of the Pulau Belimbing II Sub- Village}

The Amal play is a form of entertainment which the Pulau Belimbing II Sub-Village community looks forward to.

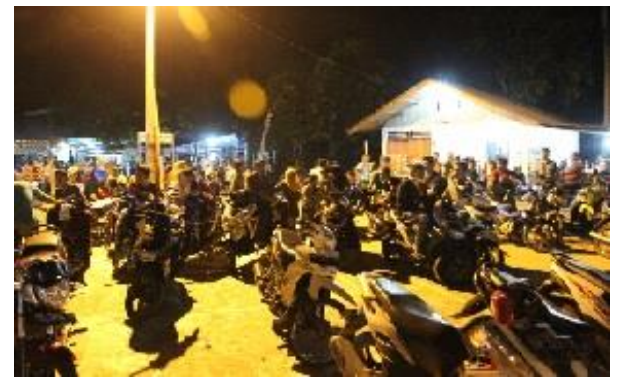

Figure 1 The lively atmosphere prior to the show at 1 Syawal 2015 of the local community coming to see the Amal Play (Image: Muklis documentation, Saadudin, 2015)

In the beginning, the Amal play was developed so that the village youth have a meaningful activity to do and keep the youth presence in the village, as told by one of the informants who was also one of the actors in the Amal play and a native of the Pulau Belimbing II Sub-Village, named Mr. Jadid:

"The Amal play used to aim as a form of entertainment which the local community can look forward to once a year. One of the village elderlies also advised that it is better that the youth not go around outside the village. Insha Allah the youth today still manages to keep the play going and active until today to perform it a week before the first night of Idul Fitri holiday [7].

As a show that is only performed once a year, this event serves as a way to build kinship among the villagers. They can see each other and have a chat in the surrounding coffee stalls near the venue of the play, or hang out at the parking lot, etc. This allows a bond to happen as the show is held during the Islamic holiday in the Syawal month, in addition to all the villagers

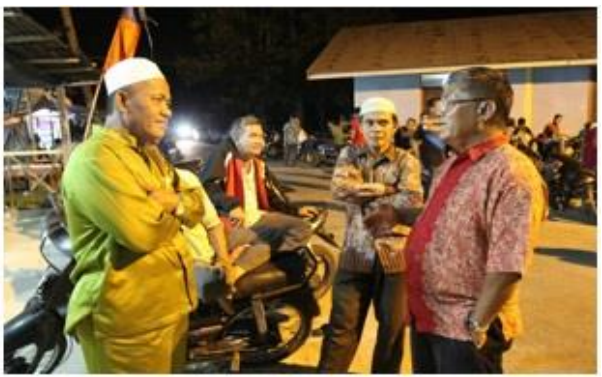

coming home for the holiday.

Figure 2 The atmosphere of silaturahmi (hospitality) among the local community in the background of a school building which served as the venue of the

Amal play (Image: Muklis documentation, Saaduddin, 2015)

One of the informants, who was also the actor and native of Pulau Belimbing village, $\mathrm{H}$. Khaidir disclosed the following:

"The Amal play is a place to get together with friends who work away and return home for the Idul Fitri holiday. We get together to watch the play, but also to see and catch up with friends whom we have not seen in a while. This is why many people look forward to the play, as there are many things to do" [9].

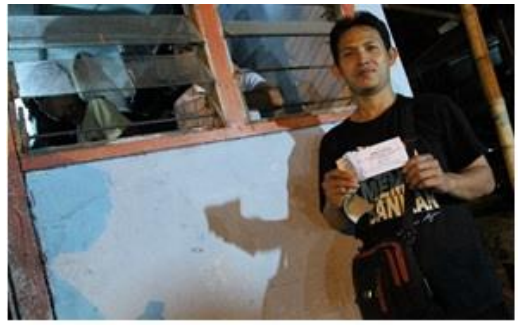

Figure 3 The author took a picture in the ticketing booth (Image: Muklis' documentation, 2015)

There is a high enthusiasm among the people of Pulau Belimbing II Sub-Village to see the Amal play. Some of the audience even comes from outside the Pulau Belimbing II Sub-Village. The venue of the Amal play at the time, the building of MDA (Madrasah Diniah Awaliah) was filled with people excited to see the Amal play. 


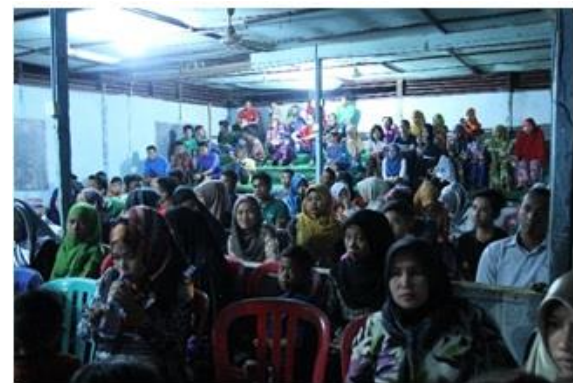

Figure 4 Local community attending the Amal play (Image: Saaduddin, 2015)

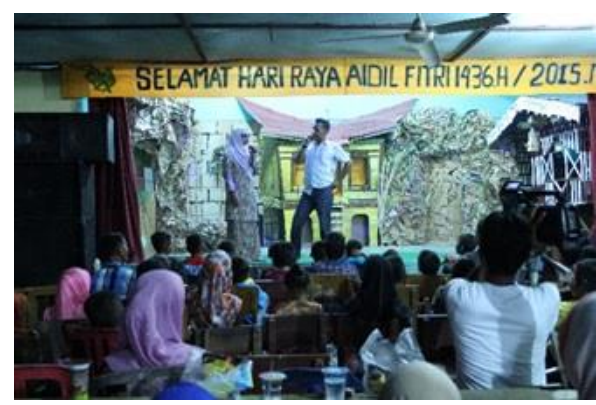

Figure 5 Local community attending the Amal play (Image: Saaduddin, 2015)

The Amal play has no formal script of the play, there is no fixed linearity of a complex plot with Aristotle theatrical plot. The boundaries between the actors and the audience are blurred with the spectacles and interaction between the actors and the audience. Each show performed uses guidance and instructions to develop each part of the play. Hence, in this case, there is a demand for each actor to do quick improvisation and creativity levels to advance the plot accurately, as explained by H.Khaidir.s.Pd.I [10]:

"In the 1950's to 1970's, some of the shows used a script, but today, most of the scripts are unfinished. The script is formed in the transition of scenes when the actors are behind the scene. Actors take turn behind the scene discussing on how to develop the show. Today, when the actors are given a script, none of them fully memorize their lines. This is why the show no longer uses a script. In the past, my father used to make scribbles for the script, but he memorized them."

\subsection{Travesty: Expression of Cultural Negotiation}

Travesty refers to the term used for a folk theater show where male actors play female roles in the plays. The term is identical with the East Javanese traditional show of Ludruk, as explained by Ayu Sutarto. In the explanation, it is stated that in the understanding, the art form which uses travesty is considered secular and recognizes the role. Some Moslems consider Ludruk as a secular art form because of tandak ludruk female character which is played by a male actor (travesty) [5].
Travesty is typically played by actors of the Amal play who are young men from the Pulau Belimbing II Sub-Village, in characters such as doctors, ustazah, housewives, singers, to girls.

Around the 1970's, there was a change as travesty was no longer used for a number of years, until it is used in the Amal play. This may refer to the decision to consider the provision of tradition which rules the norms for women in the Pulau Belimbing II SubVillage [10].

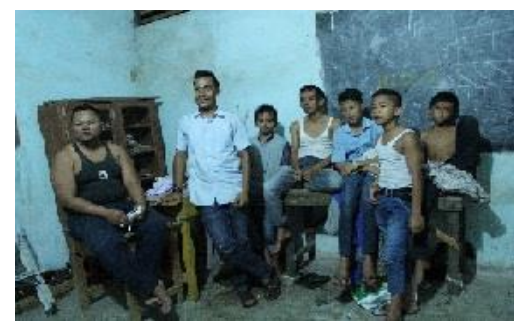

Figure 6 The male actors take turn playing the female characters behind the scene (Image: Muklis, Saaduddin, 2015)

cultural negotiation is a dialectical process of the show and audience in the Amal play. This is supported by the spontaneous interaction in the form of improvisation which forms a collective awareness. This improvisation is what allows the effort of improving collective awareness in the community on various issues and view the phenomenon among the community, whether current events or cultural practices.

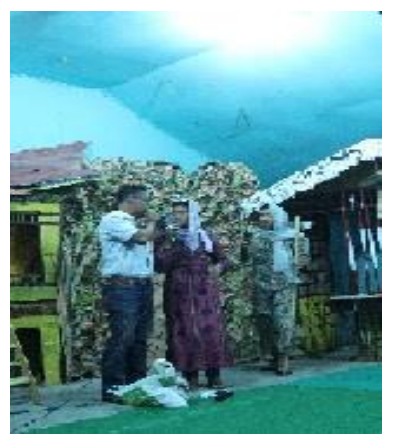

Figure 7 Female characters are played from the male characters in Figure 7. (Image: Muklis, Saaduddin, 2015)
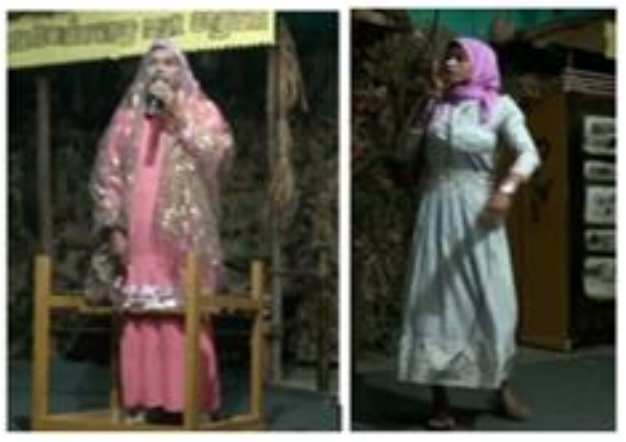

Figure 8 Actors using costumes as a mother character and ustazah character (Image: screenshot of the video recording, Padai, 2013). 
Cultural negotiation is evident in the travesty practice in the show of the Amal play. The travesty practice for the community of Pulau Belimbing II SubVillage is not viewed or implemented as a secular culture. The travesty in Amal play is a new form of expression of the community to give the alienation effect to the audience. The awareness to distance the show and the audience is done with travesty as the strength of the folk theater.

In addition, the most apparent negotiation is the practice of using the ethnic elements in the music, which can be articulated through music. In addition to ethnical elements which are interpreted in musical negotiation, ethnical elements can be read as an effort of flexible cultural assimilation or negotiation [13]. In regard to this, the negotiation of the musical aspects can be seen in the musical elements used in the Amal play.

The use of music as the element which completes the Amal play is presented using traditional music instruments such as gendang, tambur, violin, and accordion, which create Malay rhythm musical pattern [2]. Nevertheless, the Amal play show has presented pop and dangdut music as a part of entertainment for the audience. Negotiation in the musical practice can consistently be seen in the Amal plays since the time the research was conducted in 2015. Incorporating pop and dangdut music is one of the ways that the folk theater remains relevant with the community.

\section{CONCLUSION}

As a form of art expression of the agrarian society, the play Amal slowly offers dialectics for the society on the cultural practice that they have long done. Using the local wisdom pattern which is included in Jakob Soemardjo's criteria of folk theatre, the Amal play has nurtured the community's cultural life that is reflected as a cultural negotiation.

The cultural negotiation mentioned is depicted in the travesty practice in the play Amal. The travesty practice is also directed toward secular culture, although for the people of the Pulau Belimbing II SubVillage, it is not viewed or carried out as a culture of secularism as understood by the academics. The travesty in the Amal play is a new form of expression for the community to provide an effect of alienation for the audience. That awareness to give a distance between the show and the audience is done with the role of travesty as a power in this folk theatre.

The travesty practice done by the actors in the Amal play is not as transgender characters that are instilled in each actor, but as a consciousness of playing different characters. Each actor gets the role of female characters according to the needs of the show. Meanwhile, the practice of cultural negotiation is carried out among the people of Pulau Belimbing and responded in the public domain during the first week of the Syawal month every year. The practice of cultural negotiation has a space and has adapted to the long existing local wisdom values.

\section{ACKNOWLEDGMENT}

The author would like to thank researchers such as Mardiah, Hasan, Husin, and Muklis for conducting previous studies on the Amal play, as well as the informants for completing the data for this research.

\section{REFERENCES}

[1] H. Hasan and S. Saaduddin, "Fungsi Sandiwara Amal Di Masyarakat Desa Pulau Belimbing, Kec Bangkinang Barat, Kab Kampar Provinsi Riau [The Function of Charity Play in the Village Community of Pulau Belimbing, West Bangkinang District, Kampar District, Riau Province]." Ekspresi Seni, 17(1) (2015) 1-19. DOI: 10.26887/ekse.v17i1.25.

[2] Husin, "Kajian Struktur Dan Fungsi Sandiwara Amal Di Desa Belimbing, Kec. Bangkinang Barat, Kab. Kampar Prop. Riau [Study of the Structure and Function of Charity Play in the Village of Belimbing, Kec. West Bangkinang, Kab. Kampar Prop. Riau].” STSI Padangpanjang, 2007.

[3] J. Soemardjo, "Perkembangan Teater dan Drama Indonesia [Development of Indonesian Theater and Drama]." Bandung: STSI Press, 1997.

[4] S. Pamungkas, "Ludruk Karya Budaya Di Tengah Hiruk Pikuk Perubahan Budaya (Perspektif Islam) [Ludruk Cultural Works Amid the Hustle and bustle of Cultural Change (Islamic Perspective)]." Universitas Islam Negeri Sunan Ampel Surabaya, 2016.

[5] A. Sutarto, "Menguak Pergumulan Antara Seni, Politik, Islam dan Indonesia [Uncovering the Struggle Between Art, Politics, Islam and Indonesia.]." Jember: Kelompok Peduli Budaya dan Wisata Daerah Jawa Timur (Kompyawisda), 2004.

[6] BPS Kabupaten Kampar, Kecamatan Kuok Dalam Angka 2019 [Kuok District in Numbers 2019]." BPS Kabupaten Kampar, 2019.

[7] Mardiah, "Perkembangan Bentuk Pertunjukan Sandiwara Amal Kampung di Dusun Pulau Belimbing II Desa Kuok Kecamatan Kuok Kabupaten Kampar Provinsi Riau [Development of Village Charity Performances in Pulau Belimbing II Hamlet, Kuok Village, Kuok District, Kampar Regency, Riau Province]." Institut Seni Indonesia Padangpanjang, 2015.

[8] Sudasri (2015). Personal interview

[9] Khaidir (2020, April 4). Personal interview

[10] Khaidir (2020, August 3). Personal interview 
[11] B. Brecht, Schriften zum Theater. Berlin: Suhrkamp Verlag., 1969.

[12] I. Hayati, "Verfremdungseffekt (Efek Alienasi) Dalam Teks Drama Mutter Courage Und Ihre Kinder Karya Bertolt Brecht [Verfremdungseffekt (Alienation Effect) in the Drama Text Mutter Courage Und Ihre Kinder by Bertolt Brecht]." Allemania, 2 (2) (2013) 115-125. [Online]. Available: https://ejournal.upi.edu/index.php/allemania/a rticle/view/139.

[13] M. H. Raditya and G. R. L. L. Simatupang, "Negosiasi Kultural dan Musikal Dangdut Koplo pada Orkes Melayu Sonata di Jombang [Cultural Negotiations and Dangdut Koplo Musicals at the Sonata Malay Orchestra in Jombang]." Panggung, 28 (4) (2018) 434-451. DOI:http://dx.doi.org/10.26742/panggung.v28 i4.711.g421. 